\title{
IAMJ
}

INTERNATIONAL

AYURVEDIC

MEDICAL JOURNAL

\section{ROLE OF PANCHA SHIRISHA AGAD IN THE MANAGEMENT OF DADRU KUSTHA:} A REVIEW

\section{Trupti Mahapatra ${ }^{1}$, S. R. Inchulkar ${ }^{2}$, Sangeeta Bhagat ${ }^{3}$}

${ }^{1}$ P.G. Scholar, ${ }^{2}$ Professor \& HOD, ${ }^{3}$ Lecturer,

Department of Agad Tantra Evam Vidhi Ayurved, Govt Ayurvedic College, Raipur, Chhattisgarh, India

Corresponding Author: trupti1.mayee@gmail.com

https://doi.org/10.46607/iamj5208102020

(Published online: October 2020)

Open Access

(C) International Ayurvedic Medical Journal, India 2020

Article Received: 18/09/2020 - Peer Reviewed: 19/09/2020 - Accepted for Publication: 20/09/2020

Check for updates

\section{ABSTRACT}

Skin is the priority of every human but in our modern era the changing of lifestyle creating various types of disorder in body including skin disorders. There is a definite increase in its incidence especially in tropical and developing countries like India due to various reasons. In Ayurveda science all kind of skin disorder are included under kustha which is classified into two types - Kshudra and Maha Kustha. Dadru is described under kshudra kustha. In modern science clinical presentation of Dadru can be compared with dermatophytosis. It's caused by species of pathogenesis related to fungi (dermatophytes) having itching, scaling, erythema with the lesions discoid in shape. To control the effect of the disease other systems of medicine have greatly advanced, particularly in skin disorders there is no specifics medicaments for sure cure in skin disorder but symptomatic treatments like steroids are used, but they produce serious a lot of side effects in our body externally as well as internally. Ayurveda deals with the treatment which demolish the root cause by balancing the Dosha, Dhatu of body. In Charak shamita Panch shirisha Agad is described for the management of Dushi Visha (cumulative toxicity). In Agad tantra Dadru (Twak vikara) is one of the symptoms of Dushi Visha. So here an effort is made to see the review on role of Panchasirisha Agad in the management of Dadru kustha. 
Keywords: Dadru kustha, Ring worm (Dermatophytosis), Pancha shirisha Agad, Dushi Visha etc.

\section{INTRODUCTION}

The skin is the largest organ of our body covering the entire body surface besides reflecting youth and aged, color and complexion. It performs multiple functions: Protection against mechanical trauma, UV light and infections, thermoregulation, conversion and excretion of fluid, sensory perception and is an organ for synthesis of Vitamin - D from sun light. ${ }^{1}$

According to Ayurveda Twak is formed by the Paka(metabolism) of Rakta Dhatu (i.e. blood). ${ }^{3}$ The Pitta situated in skin is known as Bhrajak Pitta, which absorbs drugs applied externally in the forms of Abhyanga, Parisheka and Lepana (Massage bath, dipping, paste ) ${ }^{4}$. According to Ayurveda function of Twacha can be summarized as:

- Seat of Bhrajak Pitta.

- Seat of Sparshendriya.

- Twacha (skin) is the Upadhatu of Mansha Dhatu (i.e. muscle).

- Twacha not only helps to understand touch sensation but it also covers the whole body.

- Functioning of thermostat through sweat channels (Swedavahi Shroatas).

Dadru/Dermatophtosis: Dadru can be correlated in modern science as dermatophytosis. Dermatophytes are fungi capable of causing superficial skin infections known as ringworm or dermatophytosis. The causative fungi belong to the genera (microsporum, tricophytum and epidermophtum). They can originate from soil (geophilicy) or animals (zoophilicy) or be confined to human skin (anthropophily). Clinical forms of cutaneous infection include Tinea porphoris (involvement of the body having red scaly rashes), Tinea capitis (scalp involvement), Tinea cruris (growing involvement), Tinea pedies (involvement of the feet) and Onychomycosis (involvement of nail). ${ }^{5}$
Kustha is considered as one of the Asthamahagada. ${ }^{6}$ Dadru is one of the commonly occurring skin disease which have been included under the Maha kustha by Acharya Sushruta ${ }^{4}$ and Vagbhatta and majority of other authors considered it among the kshudra kustha. According to Dalhana, commentary on Sushruta Shamita Dadru can be classified into two - Sita and Asita ${ }^{8}$. Dalhana interprets that Dadru mentioned by Sushruta under Maha Kustha must be Asita type of Dadru because its chronicity affects the Dhatus one after the other gradually associated with excessive pain. Dadru which is enumerated by Acharya Charaka under Khudra Kustha must be Sita type because of non-involvement of Tridosha..$^{9}$ As Charaka and Vagbhata included Shirisha (Albiizia lebbeck (Linn.) as Vishaghna and Kusthagna Dravya. ${ }^{10}$ so here a review for Pancha Shirisha Agad for the management of Dadru Kustha. Based on co-relation of symptomatology, most of the scholars compared Dadru with dermatophytes though in modern perspective it comes under superficial fungal infection of the skin i.e. Ringworm. The most common dermatological manifestation affecting up to $15 \%$ of world's population in all age groups.

Materials and Method: This paper is based on textbook of Ayurveda like Brihataryi, Laghutaryi, Kriya sharia Sharira, Kaya Chikitsa etc. along with Modern textbooks and various websites to collect information on the relevant topics.

Management: Lepa means the one which is used for external application. Medicines that are in the form of a paste and used for external application, usually applied against the hair follicular direction, this facilitates the quicker absorption of the drug potency through Romakupa (Hair roots), Swedavahini (sweat glands) and Siramukha (Blood capillaries) 11. 


\section{Contents of Panchsirisha Agad ${ }^{12}$}

\begin{tabular}{|l|l|l|l|l|}
\hline Shirisha Mula & Shirisha Patra & Shirisha Twak & Shirisha Kanda & Shrisha Puspa \\
\hline (root) & (leaf) & (bark) & (Stem bark) & (Flower) \\
\hline
\end{tabular}

Sirisha roots, bark, stem bark, leaf, flower.

Sirisha (Albiizia lebbeck Linn.) is one of the drugs of choice of many Yogas by different Acharyas. Acharya Charaka and Vagbhata considered it as the drug of choice for anti-toxicity. It can be given singly or combined with many other drugs. Pancha Shirisha Agad is described by Acharya Charka in Visha Chikitsa for external application to reduced toxicity. Almost in all Ayurveda Samhita, found Sirisha as the drug of choice as Vishghna as well as Kusthaghna. The Pancha Sirisha Yoga is mainly effective because of its Prabhaba (synergic action). ${ }^{13}$

\section{Rasa Pancahk of Shirisha (Albiizia Lebbeck Linn.)}

\begin{tabular}{|l|l|l|l|l|}
\hline Rasa & Guna & Veerya & Vipaka & Karma \\
\hline Kashaya, Tikta, Madhura & Laghu, Rukshya & Anushna & Katu & Tridosha hara \\
\hline
\end{tabular}

Due to the prabhaba, Sirisha (Albiizia lebbeck Linn.) is used as Vishaghna. ${ }^{14}$

Chemical Constituents \& Properties ${ }^{12}$ : - It's having the properties like anti-inflammatory, anti-histaminic, anti-fungal, anti-microbial, anodyne and restorative in the plant. Chemical constituents of the plant: the bark yields tannins of condensed type viz. D-catechin, isomers of leucocyanidine and melacacidin. It also gives beta-sitosterol. Seeds gave calcium, phosphorus, iron, ascorbic acid, histidine and valine. The flowers contain lupeol and a pigment similar to crocetin. ${ }^{15}$ The bark is astringent, bitter, acidic, sweet, mildly thermogenic. It's useful in vitiated conditions of vata and pitta. skin eruptions, leprosy, leukoderma, wounds, ulcer, inflammation. The seeds are used in skin diseases like leprosy, leukoderma, and poisoning. ${ }^{16}$ Review of Shusruta Samhita found different yogas having Sirisha (Albiizia lebbeck Linn.) as an ingredient used in Dadru. Acharya Charaka also described different Lepas as Kusthaghna as well as Vishaghna having Sirisha (Albiizia lebbeck Linn.) in it.

\section{DISCUSSION}

There are many Agada Yogas these Yogas mainly acts because of its Prabhava(synergic action). In Ashtanga Hridaya while explaining about Agroushadha it is mentioned that Sirisha is the best medicine for Visha(poison) and Acharya Charaka described as Lepa which act as Kusthaghna. The Lakshanas (symptoms) of Dadru can be observed like Kandu, Pidaka, Raaga, and also Rooksha, Daha, Visarpini .In this review common causative factor of this disease like The factors aggravating Some amount of mild toxin is enfeebled by intrinsic and extrinsic factor remains latent in dhatus (tissues) and labeled as Dushi Visha(cumulative toxicity) like Dooshitha Desa, Kaala (polluted land and atmosphere), Anna (toxic food), Divaswapna (day sleep). Dushi Visha on vitiation produced toxicity all over body skin is the external source so it affects the most. Today's changed lifestyle like irregular diet, pollution, stress, hormonal changes are directly increasing toxicity level in the body which effect the skin and causes many skin diseases (Dermo fungal infection). According to Modern medical science, warm \& humid climate, is the chief cause of Tinea infection. Hence the shape of the lesions is not same everywhere.it differs by depending upon climate and environment.

Mode of Action: Lepa is Vahiparimarjana chikitsa (external therapies). This treatment method is specially meant for the Twakgata vikaras (skin disorders). The Lepa chikitsa also facilitates the expulsion of the Doshas locally hence, Pancha Shirisha Agad is used as Lepa. From the chemical composition having histidine, melacacidin, leucocyanidine, catechin, of the drug which have the properties of anti-fungal, so it can be 
clearly review that it will be an effective drug for Dadru.

\section{CONCLUSION}

Dadru (dermatophytosis) requires a proper methodological treatment though it is a curable disorder of skin. In various Shamitas Shirisha described under Vishaghna as well as Kusthghna formulation. Acharaya Charaka described a chapter About Vahirparimarajaniya Chikitsa there is also description of Shirisha as a best Vishaghna and Kusthghna drug. Hence the above review concluded that Pancha Shirisha Agad may be very effective in Dadru (Dermatophytosis/Ring worm).

\section{REFERENCES}

1. Harsh Mohan; A Textbook of Pathology, Jaypee Brothers' Medical Publications., $10^{\text {th }}$ Edition, Page No.808.

2. Edited by Nicki R. Colledge, Brian Walker \&Stuart H. Ralston, Publisher Churchill Livingstone $21^{\text {st }}$ Edition Page No.1272.

3. Bramhananda Tripathy, Astanga Hridaya, Chaukhamba Sanskrit Publication, Page No.367.

4. Vaidya Ambika Datta Shastri, Shusrut Shamita, Chaukhamba Sanskrit Publication, Page No.115.

5. Murthy Srikantha K.R., Astanga Hridaya, Chaukhamba Sanskrit Publication, ${ }^{\text {st }}$ Edition, Vol 2 P.83.

6. Sharma P V. (Ed), Shusruta Samhita, Vol.2; Chaukhamba Sanskrit Publication, Page 37.

7. Murthy Srikantha K.R., Astanga Hridaya, Chaukhamba Sanskrit Publication, ${ }^{\text {st }}$ Edition, Vol 2 P.140.

8. Sharma P.V.(Ed). Shusrut Shamita Varanasi, Chaukhamba Vis-Vabharati; Vol2 P.38.

9. Barmahanand Tripathi; Charaka Shamita, Chaukhamba Surbharati Prakashan, Vol.2 Page No.197

10. Bramhananda Tripathy, Astanga Hridaya, Chaukhamba Sanskrit Publication, Page No.259.

11. Sharma P.V.(Ed). Shusrut Shamita Varanasi, Chaukhamba Vis-Vabharati; Page No.128.

12. P.V Sharma Dravya Guna Vigyan, Chaukhmba Sanskrit Prakashn; Vol2, Page 112

13. P.V. Sharma; Dravya Guna Vigyan, Chaukhmba Sanskrit Prakashn; Vol1, Page 32

14. Dr. Bramahanada Tripathi, Chaukhamba Sanskrit Publication; Page No.149
15. M. B Yeine, T.J. Dennis, K.V. Billore, B.G, Chaudhari. Database On Medicinal

Plants Used In Ayurveda Vol.2 Published By: CCRAS India; Page No.447.

16. K.R. Kritikar \& Major. B. D. Basu, Indian Medicinal Plants; Vol.Iii. Page 338.

\section{Source of Support: Nil \\ Conflict of Interest: None Declared}

How to cite this URL: Trupti Mahapatra et al: Role Of Pancha Shirisha Agad In The Management Of Dadru Kustha: A Review. International Ayurvedic Medical Journal \{online\} 2020 \{cited October, 2020\} Available from: http:/www.iamj.in/posts/images/upload/4885 4888.pdf 